\title{
pH-Regulated Nonelectrogenic Anion Transport by Phenylthiosemicarbazones
}

\author{
Ethan N. W. Howe, ${ }^{\dagger}$ Nathalie Busschaert, ${ }^{\dagger \dagger}$ Xin Wu, ${ }^{\dagger}$ Stuart N. Berry, ${ }^{\dagger}$ Junming Ho ${ }^{\S}$ Mark E. Light, ${ }^{\dagger}$ \\ Dawid D. Czech, ${ }^{\dagger}$ Harry A. Klein, ${ }^{\dagger}$ Jonathan A. Kitchen, ${ }^{*}{ }^{\dagger}$ and Philip A. Gale ${ }^{*}{ }^{\dagger}$ \\ ${ }^{\dagger}$ Chemistry, University of Southampton, Southampton, SO17 1BJ, U.K. \\ ${ }^{\S}$ Institute of High Performance Computing, Agency for Science Technology and Research, 1 Fusionopolis Way, \#16-16, Connexis, \\ Singapore 138632
}

\section{Supporting Information}

ABSTRACT: Gated ion transport across biological membranes is an intrinsic process regulated by protein channels. Synthetic anion carriers (anionophores) have potential applications in biological research; however, previously reported examples are mostly nonspecific, capable of mediating both electrogenic and electroneutral (nonelectrogenic) transport processes. Here we show the transmembrane $\mathrm{Cl}^{-}$transport studies of synthetic phenylthiosemicarbazones mimicking the function of acid-sensing (proton-gated) ion channels. These anionophores have remarkable $\mathrm{pH}$-switchable transport properties with up to 640 -fold increase in transport efficacy on going from $\mathrm{pH} 7.2$ to 4.0. This "gated" process is

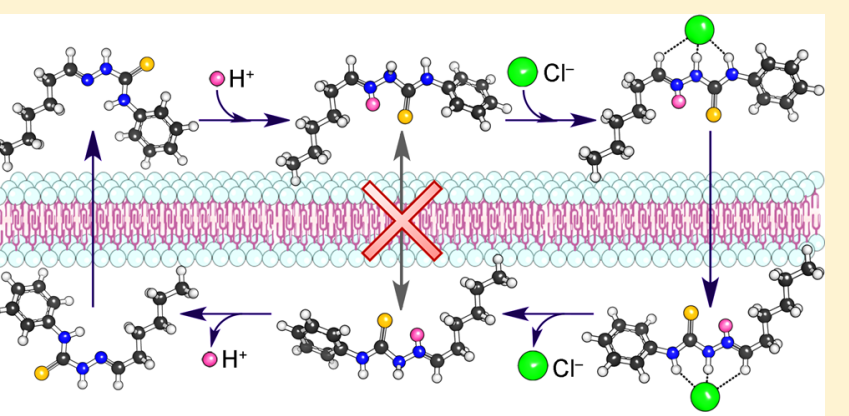

Inseparable nonelectrogenic cotransport of $\mathrm{H}^{+} / \mathrm{Cl}^{-}$ triggered by protonation of the imino nitrogen and concomitant conformational change of the anion-binding thiourea moiety from anti to syn. By using a combination of two cationophore-coupled transport assays, with either monensin or valinomycin, we have elucidated the fundamental transport mechanism of phenylthiosemicarbazones which is shown to be nonelectrogenic, inseparable $\mathrm{H}^{+} / \mathrm{Cl}^{-}$cotransport. This study demonstrates the first examples of $\mathrm{pH}$-switchable nonelectrogenic anion transporters.

\section{INTRODUCTION}

Transmembrane ion transport processes facilitated by protein channels and carriers across biological lipid bilayer membranes are essential for life. ${ }^{1}$ There has been much effort devoted to the development of small molecule anion carriers that have potential as future treatments for diseases such as cystic fibrosis or cancer. ${ }^{2}$ Prodigiosin is a natural product, best known as one of the most potent anion transporters that facilitate $\mathrm{H}^{+} / \mathrm{Cl}^{-}$ cotransport; hence, the transport of chloride can dissipate a transmembrane $\mathrm{pH}$ gradient (Figure 1). ${ }^{3} \mathrm{pH}$ gradient dissipation has been observed within cancer cells and may be a trigger for apoptosis. ${ }^{4}$ The transport of protons and chloride are inseparable because protonated prodigiosin is unable to diffuse through the lipid bilayer in the absence of chloride ${ }^{5}$ (or another bound anion, e.g. $\mathrm{Cl}^{-} / \mathrm{NO}_{3}^{-}$exchange ${ }^{6}$ ); thus, the effect of prodigiosin is nonelectrogenic. ${ }^{5}$ There are other classes of structurally similar transporters that function in a fashion similar to that of prodigiosin; these include the tambjamines, ${ }^{7}$ perenosins, ${ }^{8}$ and others. ${ }^{9}$ In the seminal work by Pérez-Tomás, Quesada et al., tambjamines were shown to induce the combined effect of cytosolic acidification and hyperpolarization of cellular membranes on cancer stem cells, leading to selective elimination of the affected cell population. ${ }^{7 \mathrm{~b}}$

Prodigiosin and other similar classes of $\mathrm{H}^{+} / \mathrm{Cl}^{-}$cotransporters are active across the $\mathrm{pH}$ range of 4-7; therefore, it would be very beneficial for biological studies if synthetic carriers could facilitate $\mathrm{H}^{+} / \mathrm{Cl}^{-}$cotransport explicitly in acidic intracellular organelles such as lysosomes. Furthermore, transporters that can effectively switch $\mathrm{ON}$ in an acidic environment, but OFF at neutral $\mathrm{pH}$, would mimic the function of acid-sensing (protongated) ion channels. ${ }^{10}$ There are only a few reports of $\mathrm{pH}$ dependent transporters, ${ }^{11}$ and carriers that possess a highly specific $\mathrm{pH}$-influenced $\mathrm{ON} / \mathrm{OFF}$ function are still unavailable. Our group, in collaboration with Jolliffe and co-workers, has previously reported thiosquaramides and an oxothiosquaramide as $\mathrm{pH}$-dependent anionophores. ${ }^{12}$ However, these carriers can mediate electrogenic transport and hence are capable of depolarizing the membrane potential; ${ }^{13}$ unfortunately, this is undesirable for certain cellular studies. ${ }^{14}$ The challenge is to develop $\mathrm{pH}$-switchable anionophores with truly prodigiosin-like transport properties.

Phenylthiosemicarbazones are structurally similar to phenylthioureas; however, they contain an additional imine group directly adjacent to the thiourea anion binding site. ${ }^{15}$ Herein we report three phenylthiosemicarbazones $\mathbf{1 - 3}$ (Figure 2) as a new class of anionophores that have excellent $\mathrm{pH}$-switchable anion transport properties. To evaluate the effect of electron-

Received: May 5, 2016

Published: June 14, 2016 


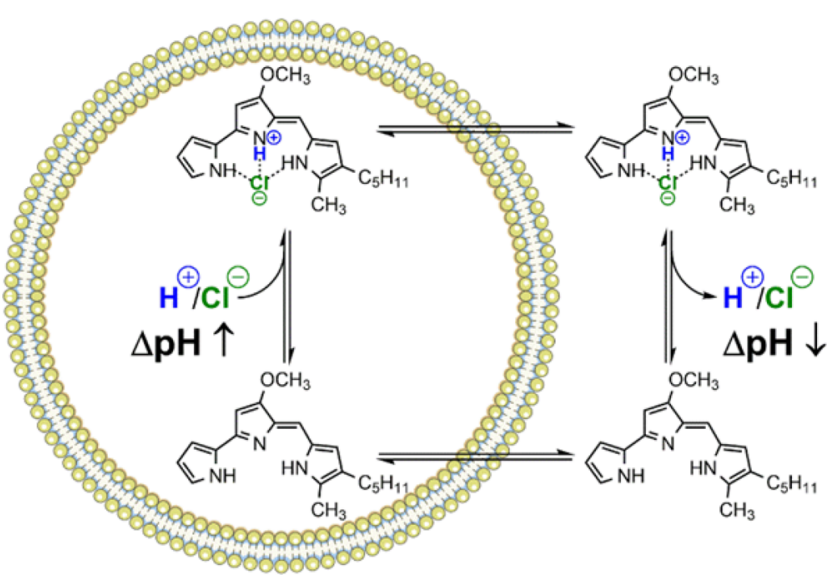

Figure 1. Prodigiosin-mediated $\mathrm{H}^{+} / \mathrm{Cl}^{-}$cotransport (symport) showing binding of chloride upon protonation at the inner membrane interface of liposomes, translocation as a neutral complex [Prod. $\left.\mathrm{H}^{+} \supset \mathrm{Cl}^{-}\right]$, and dissociation of $\mathrm{H}^{+} / \mathrm{Cl}^{-}$to the external bulk, resulting in dissipation of $\mathrm{pH}$ gradient.
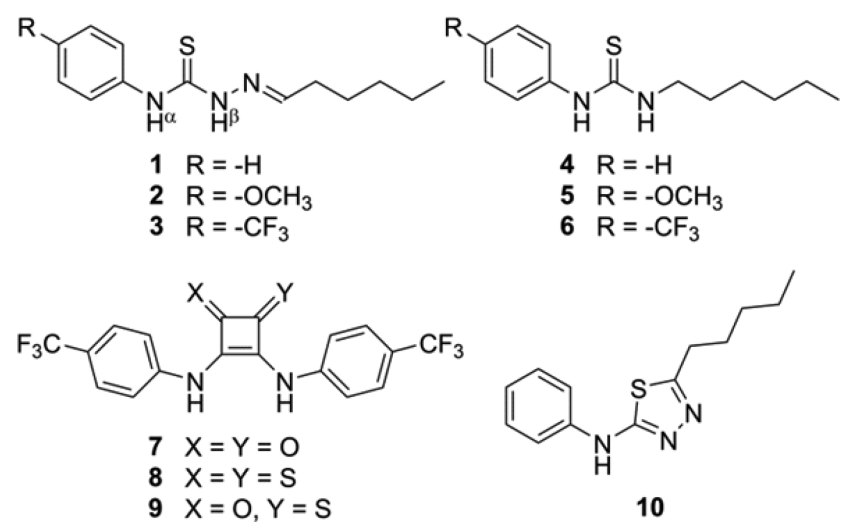

Figure 2. Structures of anionophores used in this study: thiosemicarbazones 1-3, phenylthioureas 4-6, squaramides 7-9, and phenylaminothiadiazole $\mathbf{1 0 .}$

donating or -withdrawing substituents on the para-position of the phenyl ring, the unsubstituted $1\left(\sigma_{\mathrm{p}} 0.0\right)$, methoxy $2\left(\sigma_{\mathrm{p}}\right.$ $-0.27)$, and trifluoromethyl $3\left(\sigma_{\mathrm{p}} 0.54\right)$ were synthesized. The Hammett constant $(\sigma)^{16}$ is a descriptor of the electronwithdrawing or -donating effect of a specific substituent; it has been used extensively to correlate the hydrogen bond donor acidity. ${ }^{17}$ Chloride anion binding and transmembrane transport activities of 1-hexylidene-4-phenylthiosemicarbazones 1-3 were compared with the analogous 1-hexyl-3-phenylthioureas $4-6^{17 \mathrm{c}}$ and squaramides $7-9 .^{12,18}$ Thiosemicarbazones 1-3 were found to be more effective $\mathrm{pH}$-switchable anion transporters (from neutral to acidic environment) than previously reported oxothiosquaramide 8 and thiosquaramide 9. More importantly, we have shown that chloride and proton transport by thiosemicarbazones is an inseparable electroneutral process (elucidated by using the newly developed cationophore-coupled $\mathrm{KCl}$ efflux assays from our most recent work $)^{19}$ in the same fashion as the $\mathrm{H}^{+} / \mathrm{Cl}^{-}$symport properties of prodigiosin. Therefore, we have developed the first examples of a new class of $\mathrm{pH}$-switchable nonelectrogenic anion transporters.

\section{RESULTS AND DISCUSSION}

Synthesis, Solid-State Structural Analysis, and Anion Binding Studies. Thiosemicarbazones 1-3 were synthesized by the condensation of the corresponding phenylthiosemicarbazides with hexanal in absolute ethanol, with yields of $47-52 \%$ after recrystallization from a ethanol/pentane mixture. Phenylthiosemicarbazides $\left(\mathrm{OCH}_{3}\right.$ and $\mathrm{CF}_{3}$ analogues $)$ were prepared by the reaction of hydrazine monohydrate with the appropriate phenyl isothiocyanate in 2-propanol. The rearrangement of thiosemicarbazones to five-membered heterocyclic thiadiazoles is well documented; ${ }^{20}$ therefore, 2-phenylamino-5-pentyl-1,3,4thiadiazole 10 was prepared from 1 via an oxidative cyclization and used as a control in the transmembrane transport studies.

The resolved X-ray structure of $\mathbf{1 0}$ confirmed the thiadiazole heterocyclic structure (see Supporting Information). Solid-state structures of all three thiosemicarbazones $1-3$ revealed that the thiourea moieties adopt a flat planar anti-conformation, presumably due to an intramolecular hydrogen bond $(\mathrm{H}-$ bond) between the thiourea- $\mathrm{N}(1) \mathrm{H}$ and the lone pair electrons of imino-N(3), as shown in Figure 3a for compound 3 (see

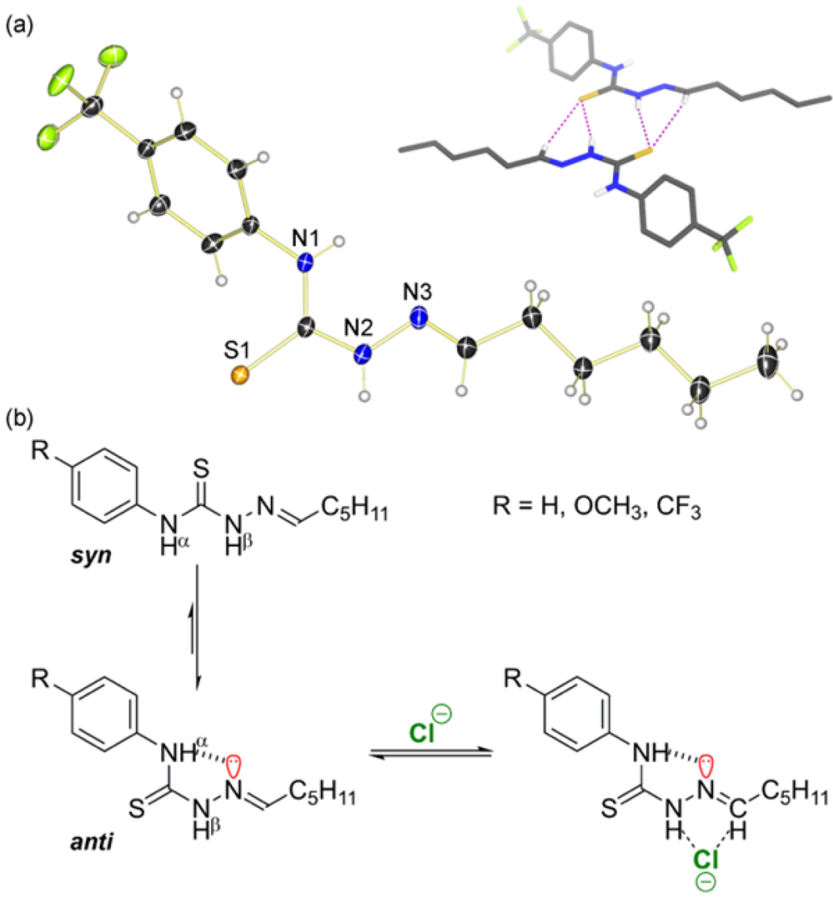

Figure 3. (a) Single-crystal X-ray structure of 3: ORTEP diagram showing $50 \%$ probability anisotropic displacement ellipsoids at $100(2)$ $\mathrm{K}$; inset: perspective packing diagram of two molecular structures, all $\mathrm{H}$ atoms are omitted for clarity, except thiourea- $\mathrm{H}$ and imine- $\mathrm{NCH}$, showing intermolecular $\mathrm{H}$-bonds (purple dashed lines), selected $\mathrm{H}$ bond (donor-acceptor) distances $(\AA)$ : $\mathrm{N}(2) \cdots \mathrm{S}(1) 3.352(1), \mathrm{N}(3)=$ C...S(1) 3.688(2). (b) Schematic equilibria of thiosemicarbazone binding conformation toward chloride anion.

Supporting Information for structures of $\mathbf{1}$ and 2). Additionally, crystal packing interactions of thiosemicarbazones are mainly established via $\mathrm{H}$-bonds between thiourea $\mathrm{N}(2) \mathrm{H} \cdots \mathrm{S}$ and an imine $\mathrm{N}=\mathrm{CH} \cdots \mathrm{S}$ interaction.

${ }^{1} \mathrm{H}$ NMR titration studies of $\mathbf{1 - 3}$ in DMSO- $d_{6} / 0.5 \% \mathrm{H}_{2} \mathrm{O}$ with tetrabutylammonium (TBA) chloride did not result in an observable change in the chemical shifts $(\Delta \delta)$, indicative of no binding. When using acetone- $d_{6}$ as a less competitive solvent, ${ }^{21}$ titration of 1-3 with TBA-Cl induced a downfield $\Delta \delta$ on the 
Table 1. Overview of Association Constants $\left(K_{\mathrm{a}}\right)$ for the Complexation of 1-9 toward $\mathrm{Cl}^{-}$and $\mathrm{NO}_{3}{ }^{-}$(as TBA salts), Obtained from ${ }^{1} \mathrm{H}$ NMR Titrations $\left(400 \mathrm{MHz}\right.$ ) at $298 \mathrm{~K}$ in DMSO- $d_{6} / 0.5 \% \mathrm{H}_{2} \mathrm{O}$ and Acetone- $d_{6} ; \mathrm{Cl}^{-} / \mathrm{NO}_{3}{ }^{-}$Transport Activity at $\mathrm{pH} 7.2$ and 4.0 Obtained from Hill Analysis and Calculated $\log P$ Values

\begin{tabular}{|c|c|c|c|c|c|c|c|c|c|}
\hline \multirow[b]{2}{*}{ compound } & \multirow[b]{2}{*}{$\begin{array}{c}\mathrm{K}_{\mathrm{a}} \mathrm{Cl}^{-}\left[\mathrm{M}^{-1}\right] \\
\text { DMSO- } d_{6}\end{array}$} & \multirow[b]{2}{*}{$\begin{array}{c}K_{\mathrm{a}} \mathrm{Cl}^{-}\left[\mathrm{M}^{-1}\right] \\
\text { acetone- } d_{6}\end{array}$} & \multirow[b]{2}{*}{$\begin{array}{c}K_{\mathrm{a}} \mathrm{NO}_{3}^{-}\left[\mathrm{M}^{-1}\right] \\
\text { acetone- } d_{6}\end{array}$} & \multicolumn{2}{|c|}{$\begin{array}{c}\mathrm{Cl}^{-} / \mathrm{NO}_{3}^{-} \text {at } \\
\mathrm{pH} 7.2\end{array}$} & \multicolumn{2}{|c|}{$\begin{array}{c}\mathrm{Cl}^{-} / \mathrm{NO}_{3}^{-} \text {at } \\
\mathrm{pH} 4.0\end{array}$} & \multirow[b]{2}{*}{$\mathrm{EC}_{50}(\mathrm{pH} 7.2) / \mathrm{EC}_{50}(\mathrm{pH} 4.0)^{b}$} & \multirow[b]{2}{*}{$\mathrm{c} \log P^{c}$} \\
\hline & & & & $\begin{array}{c}\mathrm{EC}_{50} \\
{[\mathrm{~mol} \mathrm{\%}]^{a}}\end{array}$ & $n^{a}$ & $\begin{array}{c}\mathrm{EC}_{50} \\
{[\mathrm{~mol} \mathrm{\%}]^{a}}\end{array}$ & $n^{a}$ & & \\
\hline 1 & $-{ }^{d}$ & $16^{e}$ & $3.3^{e, h}$ & 4.7 & 2.3 & 0.0074 & 1.3 & 640 & $3.81(0.52)$ \\
\hline 2 & $-{ }^{d}$ & $18^{e}$ & $3.2^{e, h}$ & 1.8 & 1.3 & 0.0073 & 1.2 & 250 & $3.74(0.58)$ \\
\hline 3 & $-{ }^{d}$ & $31^{e}$ & $4.3^{e, h}$ & $\gg 10^{j}$ & $-^{j}$ & 0.13 & 0.7 & $\gg 77$ & $4.70(0.52)$ \\
\hline 4 & $13^{k}$ & $9.2 \times 10^{3 f}$ & $250^{f}$ & $2.7^{k}$ & $0.9^{k}$ & 2.2 & 0.9 & 1.2 & $3.63(0.35)$ \\
\hline 5 & $11^{k}$ & $3.8 \times 10^{3 f}$ & $120^{f}$ & $5.5^{k}$ & $1.3^{k}$ & 4.3 & 1.0 & 1.3 & $3.64(0.42)$ \\
\hline 6 & $26^{k}$ & $2.5 \times 10^{4 f}$ & $780^{f}$ & $0.44^{k}$ & $1.7^{k}$ & 0.51 & 1.3 & 0.86 & $4.62(0.31)$ \\
\hline 7 & $460^{k}$ & $>10^{5 g, i}$ & $1.7 \times 10^{4 g}$ & $0.065^{k}$ & $1.2^{k}$ & $0.077^{k}$ & $1.3^{k}$ & 0.84 & $4.43(0.90)$ \\
\hline 8 & $60^{k}$ & $--^{m}$ & $-m$ & $0.68^{k}$ & $0.8^{k}$ & $0.013^{k}$ & $6.3^{k}$ & 52 & $5.39(0.69)$ \\
\hline 9 & $470^{l}$ & $--^{m}$ & $--^{m}$ & $0.22^{l}$ & $1.9^{l}$ & $0.027^{l}$ & $2.6^{l}$ & 8.1 & $4.94(0.66)$ \\
\hline
\end{tabular}

${ }^{a}$ Chloride efflux $\left(\mathrm{Cl}^{-} / \mathrm{NO}_{3}{ }^{-}\right.$antiport) measured by chloride-ISE from POPC LUVs (mean diameter $\left.200 \mathrm{~nm}\right)$ loaded with $\mathrm{NaCl}(\sim 500 \mathrm{mM})$ and suspended in $\mathrm{NaNO}_{3}(\sim 500 \mathrm{mM})$, buffered to $\mathrm{pH} 7.2$ and 4.0 with phosphate $(5.0 \mathrm{mM})$ and citrate $(5.0 \mathrm{mM})$ sodium salts, respectively. Hill analysis was performed to obtain the effective concentration to achieve $50 \% \mathrm{Cl}^{-}$efflux $\left(\mathrm{EC}_{50}\right)$ at $270 \mathrm{~s}$ for each carrier, shown as carrier:lipid molar percent, and Hill coefficient $(n)$ reveals the stoichiometry of active carrier ${ }_{n}$ :anion supramolecular complex mediating the transmembrane transport. ${ }^{23}$ ${ }^{b} \mathrm{EC}_{50}(\mathrm{pH} 7.2) / \mathrm{EC}_{50}(\mathrm{pH} 4.0)$, an indicator for $\mathrm{pH}$-switchable transport efficacy. ${ }^{c}$ Averaged log $P$ values (with error in parentheses) calculated via VCCLab. ${ }^{24}{ }^{d}$ No change in $\Delta \delta$ observed. ${ }^{e} K_{\mathrm{a}}$ derived from global fitting analysis of $\Delta \delta$ for $\mathrm{NH}^{\beta}$ and NCH signals. ${ }^{f} K_{\mathrm{a}}$ derived from global fitting analysis of $\Delta \delta$ for $\mathrm{NH}^{\alpha}$ and $\mathrm{NH}^{\beta}$ signals. ${ }^{g} K_{\mathrm{a}}$ derived from global fitting analysis of $\Delta \delta$ for $\mathrm{NH}$ and ArH signals to the 1:1 binding model. ${ }^{22}{ }^{h}$ Very weak binding $\left(K_{\mathrm{a}}<5 \mathrm{M}^{-1}\right)$ association constant values may be inaccurate. ${ }^{i}$ Very strong binding $\left(K_{\mathrm{a}}>10^{5} \mathrm{M}^{-1}\right)$; the calculated association constant is beyond the upper limit that can be reliably obtained from ${ }^{1} \mathrm{H}$ NMR titration studies. ${ }^{22 a}{ }^{j}$ Too inactive for Hill analysis: 10 mol $\%$ loading of 3 resulted in $15 \% \mathrm{Cl}^{-}$efflux at $270 \mathrm{~s} .{ }^{k}$ Previously reported by Busschaert et al. ${ }^{12 a, 17 c, 18}{ }^{l}$ Previously reported by Elmes et al. ${ }^{12 \mathrm{~b}} \mathrm{~m}^{\mathrm{m}}$ Not determined.

resonance signals of thiourea- $\mathrm{NH}^{\beta}$ and imine- $\mathrm{NCH}$, indicating $\mathrm{Cl}^{-}$binding to the thiosemicarbazones via a cleft formed by $\mathrm{NH} / \mathrm{CH}$ hydrogen donors. This suggests that the conventional anion binding thiourea moiety is "locked" by the intramolecular $\mathrm{H}$-bond interaction between $\mathrm{NH}^{\alpha}$ and the lone pair electrons of imino nitrogen (Figure $3 \mathrm{~b}$ ). The resulting $K_{\mathrm{a}}$ (Table 1 ) derived from global fitting analysis ${ }^{22}$ revealed weak binding toward both $\mathrm{Cl}^{-}$and $\mathrm{NO}_{3}{ }^{-}$with similar trends $(3>1 \approx 2)$. Expectedly, the binding of phenylthioureas 4-6 to $\mathrm{Cl}^{-}$in acetone- $d_{6}$ was significantly stronger than previously reported studies in DMSO- $d_{6} / 0.5 \% \mathrm{H}_{2} \mathrm{O}$ mixture, and the derived $K_{\mathrm{a}}$ for binding to both $\mathrm{Cl}^{-}$and $\mathrm{NO}_{3}{ }^{-}$were 2 to 3 orders of magnitude higher than those of the analogous thiosemicarbazones. The binding of $\mathrm{Cl}^{-}$and $\mathrm{NO}_{3}^{-}$to squaramide 7 in acetone- $d_{6}$ was very strong, while $K_{\mathrm{a}}$ for $\mathrm{Cl}^{-}$was too strong $\left(>10^{5} \mathrm{M}^{-1}\right)$ to be accurately determined by ${ }^{1} \mathrm{H}$ NMR titration techniques. ${ }^{22 a}$

pH-Regulated Anion Transport Studies. The $\mathrm{pH}$ dependent chloride transport activities of compounds 1-3 and 10 were investigated using the same liposome-based anion exchange assay $\left(\mathrm{Cl}^{-} / \mathrm{NO}_{3}^{-}\right)$reported for anionophores 49. ${ }^{12,17 \mathrm{c}}$ Briefly, 1-palmitoyl-2-oleoyl-sn-glycero-3-phosphocholine (POPC) large unilamellar vesicles (LUVs, mean diameter $200 \mathrm{~nm})$ were loaded with $\mathrm{NaCl}(\sim 500 \mathrm{mM})$ and suspended in $\mathrm{NaNO}_{3}(\sim 500 \mathrm{mM})$, buffered to $\mathrm{pH} 4.0,5.0,6.0,7.2$, or 10.0 with appropriate buffer reagents $(5.0 \mathrm{mM})$. The $\mathrm{Cl}^{-} / \mathrm{NO}_{3}{ }^{-}$ exchange process was initiated by addition of carriers in a DMSO solution, and the rate of $\mathrm{Cl}^{-}$efflux to the external bulk was monitored using a chloride ion selective electrode (ISE).

The results of the $\mathrm{pH}$-dependent anion transport studies at $\mathrm{pH} 4.0$ and 7.2 are shown in Figure 4 (see Supporting Information section $\mathrm{S} 7.2$ for transport rates at other $\mathrm{pH}$ values). The anion transport activities of thiosemicarbazones 1-3 (1.0 mol \%) are clearly regulated by $\mathrm{pH}$, significantly enhanced (switches $\mathrm{ON}$ ) when going from neutral $(\mathrm{pH}$ 7.2) to acidic ( $\mathrm{pH}$ 4.0) media. Compound 10 (control) did not mediate any significant transport activity at the $\mathrm{pHs}$ studied

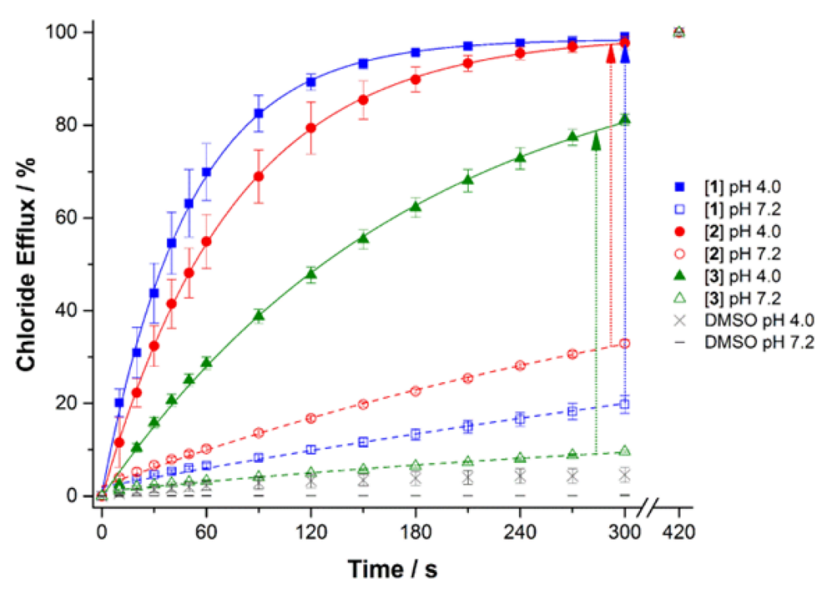

Figure 4. Plot of $\mathrm{Cl}^{-}$efflux from POPC LUVs (mean diameter 200 $\mathrm{nm})$ at $\mathrm{pH} 7.2$ and 4.0, facilitated by thiosemicarbazones $\mathbf{1 - 3}(1.0 \mathrm{~mol}$ $\%$, carrier:lipid) and monitored over a period of 5 min using chlorideISE. Detergent was added to lyse the vesicles at $300 \mathrm{~s}$, to release remaining encapsulated $\mathrm{Cl}^{-}$for the $100 \%$ chloride concentration at $420 \mathrm{~s}$. Anionophores were added as DMSO solutions $(10 \mu \mathrm{L})$ to the POPC LUVs suspension $(5.0 \mathrm{~mL})$, and the lipid concentration used was $1.0 \mathrm{mM}$. Solid and dashed lines drawn through the data points are fitted curves to calculate the initial rate of $\mathrm{Cl}^{-}$efflux, error bars corresponding to the SD from three repeats. DMSO was used as a control. Vertical dotted lines indicate the enhanced transport activities from $\mathrm{pH} 7.2$ to 4.0 .

(see Supporting Information Figure S45). A control $\mathrm{Cl}^{-} / \mathrm{SO}_{4}{ }^{2-}$ exchange assay in POPC liposomes and $\mathrm{Cl}^{-} / \mathrm{NO}_{3}{ }^{-}$exchange assay in POPC:cholesterol (7:3) liposomes were studied with 1-3 (1.0 mol \%) at $\mathrm{pH} 4.0$ (see Supporting Information section S7.4-7.5 for details and brief discussion).

Dose-response studies of anionophores at different concentrations were carried out to perform Hill analysis. ${ }^{23 a}$ This was to obtain the Hill coefficient $(n)$, which indicates the stoichiometry of active carrier $_{n}$ :anion supramolecular complex 
mediating transport and the effective concentration of transporter required to achieve $50 \%$ anion transport at $270 \mathrm{~s}\left(\mathrm{EC}_{50}\right)$ for the quantitative transport activity. ${ }^{23 \mathrm{~b}, \mathrm{c}}$ Hill analyses for 1-3 were performed at both $\mathrm{pH} 7.2$ and 4.0 and 4-6 at $\mathrm{pH} 4.0$ only. To evaluate the neutral to acidic $\mathrm{pH}$-switchable transport efficacy of the anionphore, we also reported the ratio of $\mathrm{EC}_{50}$ at $\mathrm{pH} 7.2$ to $\mathrm{EC}_{50}$ at $\mathrm{pH}$ 4.0. The Hill analysis-derived results for 1-9 are summarized in Table 1 .

In acidic aqueous media, the transport activities of thiosemicarbazones switches $\mathrm{ON}$; as a result, $\mathbf{1}$ and $\mathbf{2}$ became the most potent anionophores at $\mathrm{pH} 4.0$ from this study, with extremely low $\mathrm{EC}_{50}$ values of 0.0074 and $0.0073 \mathrm{~mol} \%$. The Hill coefficients obtained for $\mathbf{1 - 3}$ are mostly $\sim 1$, except for $\mathbf{1}$ at $\mathrm{pH} 7.2$ which has a Hill coefficient of ca. 2, suggesting a different binding mode for anion transport by $\mathbf{1}$; i.e., $1: 1$ complex at $\mathrm{pH} 4.0\left(\mathbf{1}: \mathrm{Cl}^{-}\right)$and 2:1 complex at $\mathrm{pH} 7.2\left(\mathbf{1}_{2}: \mathrm{Cl}^{-}\right)$. Interestingly, the $\mathrm{pH}$-switchable properties of thiosemicarbazones are significantly better than $\mathbf{8}$ and $\mathbf{9}$, as $\mathbf{1}$ emerged as the best $\mathrm{pH}$-switchable transporter with a remarkable $\mathrm{EC}_{50}(\mathrm{pH}$ $7.2) / \mathrm{EC}_{50}(\mathrm{pH} 4.0)$ ratio of 640 , followed by 2 and 3 with 250 and $\gg 77$, respectively, all larger than those of 8 (51-fold) and 9 (8-fold). As anticipated, there were negligible differences in the transport activities of phenylthioureas $4-6$ between $\mathrm{pH} 7.2$ and $4.0\left(\mathrm{EC}_{50}(\mathrm{pH} 7.2) / \mathrm{EC}_{50}(\mathrm{pH} 4.0) \approx 1\right)$, similar to squaramide 7.

Conformational Control by Protonation on Imino Nitrogen. Previously reported compounds 8 and 9 have low $\mathrm{p} K_{\mathrm{a}}$ values of 5.3 and 6.6, respectively; hence, the squaramide $\mathrm{NH}$ groups are deprotonated at neutral $\mathrm{pH}^{12}$ However, the thiourea $\mathrm{NH}$ groups of $\mathbf{1 - 3}$ are much less acidic $\left(\mathrm{p} K_{\mathrm{a}}>11\right.$, see Supporting Information); therefore, the $\mathrm{pH}$-switchable transport mechanism of the thiosemicarbazones is likely due to protonation of the imine group, triggering a conformational change. It is well documented that thiosemicarbazones can complex with transition metals via the thiourea sulfur and imino nitrogen atoms, ${ }^{25}$ and this can facilitate the rearrangement of the thiourea moiety to the favorable syn-conformation. ${ }^{15 \mathrm{~b}} \mathrm{p} K_{\mathrm{b}}$ (protonation of imine) measurements attempted using potentiometric methods were unsuccessful, possibly due to the values being too low. Results from 2-D ${ }^{1} \mathrm{H}-{ }^{1} \mathrm{H}$ NOESY NMR studies of 1-3 in DMSO- $d_{6}$ are consistent with the anticonformation observed in the solid-state X-ray structures. In the presence of 1 equiv of tetrafluoroboric acid $\left(\mathrm{HBF}_{4}\right)$ as a proton source, chemical exchange between the $\mathrm{NH}$ resonances of thiourea leads us to suggest that protonation of imine "unlocks" the intramolecular $\left(\mathrm{NH}^{\alpha} \cdots \mathrm{N}=\mathrm{C}\right) \mathrm{H}$-bond interaction (see Supporting Information section S8 and Figures S65-70 for details and brief discussion).

In acetone- $d_{6},{ }^{1} \mathrm{H}$ NMR titration studies with $\mathrm{HBF}_{4}$ resulted in equimolar protonation of 1-3, observable from the slow exchange between the neutral and protonated states (Figure 5, see Supporting Information Figures S71-73 for more details). Proton chemical exchange between the protonated imino- $\mathrm{NH}$ and the proximal thiourea- $\mathrm{NH}^{\beta}$ with $\mathrm{H}_{2} \mathrm{O}$ in an acidic environment was too fast to be observed on the NMR time scale. ${ }^{26}$ Nonetheless, the apparent changes in chemical shifts of the aromatic- $\mathrm{CHs}$, thiourea- $\mathrm{NH}^{\alpha}$, imine- $\mathrm{CH}$, and methylene$\mathrm{CH}_{2}$ signals are evidence that lead us to suggest that the protonation of imino nitrogen perturbed the anti-conformation of the neutral state. The reversibility between the neutral and protonated states of 1-3 was firmly established by ${ }^{1} \mathrm{H}$ NMR titration studies with $\mathrm{HBF}_{4}$ (toward saturation of protonated state at 1 equiv), followed by titration with tetrabutylammo-

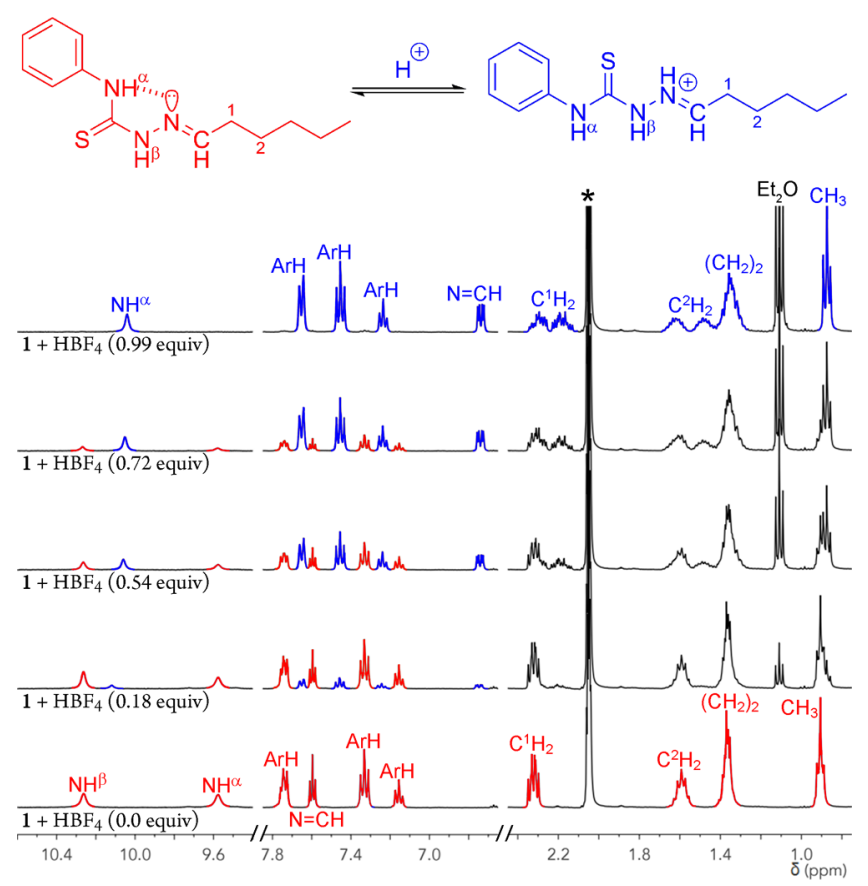

Figure 5. Selected partial ${ }^{1} \mathrm{H}$ NMR (400 MHz, $298 \mathrm{~K}$ ) spectra of compound $\mathbf{1}(11.2 \mathrm{mM})$ in $\left(\mathrm{CD}_{3}\right)_{2} \mathrm{CO}$, titrated with aliquots of $\mathrm{HBF}_{4}$. $\left(\mathrm{CH}_{3} \mathrm{CH}_{2}\right)_{2} \mathrm{O}$ solution, showing the slow exchange speciation of the neutral and protonated states of 1 . "*" and " $\mathrm{Et}_{2} \mathrm{O}$ " denote peaks of NMR solvent and diethyl ether, respectively.

nium hydroxide up to 1 equiv to achieve full recovery of the neutral state (see Supporting Information Figures S75-77 for details). It should be noted that free aldehyde (hexanal) was not observed during the NMR studies, providing evidence that the protonated thiosemicarbazones do not undergo imine hydrolysis during these experiments (see Supporting Information Figure S74). Furthermore, UV-vis studies of $\mathbf{1 - 3}$ at $\mathrm{pH}$ 4.0 demonstrated that these thiosemicarbazones are stable in the presence of liposomes, monitored over $30 \mathrm{~min}$ (see Supporting Information section S10 and Figures S78-85 for details and brief discussion), and likewise corroborate the stability of 1-3 over the duration of the anion transport experiments.

To gain further structural insights, density functional theory (DFT) calculations (SMD-M06-2X/6-31+G(d)) $)^{27}$ were performed for 1-3 (neutral and protonated) and their $\mathrm{Cl}^{-}$ complexes. The optimized structures for all three thiosemicarbazones gave the same outcomes; therefore, only structures of $\mathbf{1}$ are illustrated in Figure 6. While the neutral state of $\mathbf{1}$ showed the same anti-conformation, the host-guest complex of $1 \supset \mathrm{Cl}^{-}$correlates with the ${ }^{1} \mathrm{H}$ NMR binding studies. The structure of $1 \cdot \mathrm{H}^{+}$revealed that protonation of the imino nitrogen perturbs the intramolecular $\left(\mathrm{NH}^{\alpha} \cdots \mathrm{N}=\mathrm{C}\right) \mathrm{H}$-bond. Furthermore, the proximal planar arrangement of the imino hydrogen toward the thiourea sulfur suggests an intramolecular $\mathrm{N}^{+} \mathrm{H} \cdots \mathrm{S}$ H-bond, which contributes to the stabilization of the syn-conformation. As a result, the protonated state of $\mathbf{1}$ binds $\mathrm{Cl}^{-}$via three $\mathrm{H}$-bonds to form an overall neutral complex $\mathbf{1}$. $\mathrm{H}^{+} \supset \mathrm{Cl}^{-}$. Calculated binding energies in the gas phase revealed stronger $\mathrm{Cl}^{-}$binding toward the protonated states of 1-3 compared to the neutral species (see Supporting Information section S11 for details and discussion). This conformational control mechanism via protonation emulates the intrinsic 


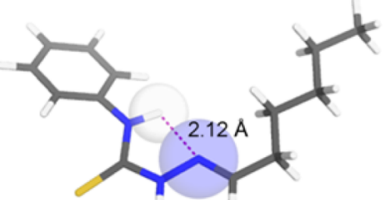

[1]
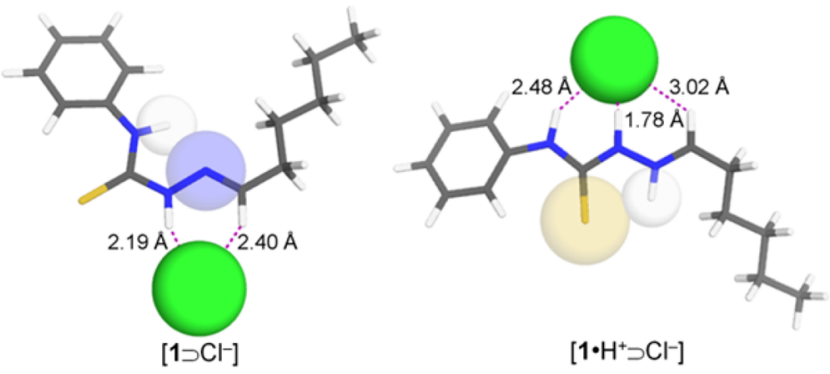

Figure 6. DFT (M06-2X/6-31+G(d))-optimized structures of $\mathbf{1}$ in neutral and protonated states, and the respective $\mathrm{Cl}^{-}$complexes, with intramolecular and intermolecular $\mathrm{H}$-bonds shown as purple dashed lines. allosteric properties of acid-sensing (proton-gated) ion channel proteins. ${ }^{10}$

We also carried out high-level ab initio calculations ${ }^{28}$ to compute the $\mathrm{p} K_{\mathrm{a}}$ (in parentheses) of the protonated conjugate acids for 1 (2.01), 2 (1.91), and 3 (1.53) in water (with uncertainty of \pm 2 , see Supporting Information). Although the $\mathrm{p} K_{\mathrm{a}}$ can differ significantly in lipid bilayers, ${ }^{29}$ the trend of $\mathbf{1} \approx \mathbf{2}$ $>3$ will remain similar; the trend suggests that the optimal $\mathrm{pH}$ for anion transport by 3 is the lowest, which provides a rationale for 3 being less active with a higher $\mathrm{EC}_{50}$. The acidity of thiourea $\mathrm{NH}^{\alpha}$ (governed by the electron-donating or -withdrawing substituents) will directly affect the strength of intramolecular $\left(\mathrm{NH}^{\alpha} \cdots \mathrm{N}=\mathrm{C}\right) \mathrm{H}$-bond, consequently resulting in the trend of predicted $\mathrm{pK}_{\mathrm{a}}$ values from competing intramolecular H-bond and solvation effects. Since $\mathrm{NH}^{\alpha}$ of $\mathbf{1}$ $(-\mathrm{H})$ is more acidic than $2\left(-\mathrm{OCH}_{3}\right)$, the $\mathrm{NH}^{\alpha} \cdots \mathrm{N}=\mathrm{C}$ H-bond present in compound $\mathbf{1}$ is thermodynamically more stable, which inhibits perturbation of the intramolecular $\mathrm{H}$-bond and the concomitant anti to syn reorganization (see Supporting Information section S11 for details and discussion). The overall result is the imino nitrogen of $\mathbf{2}$ can be expected to be more
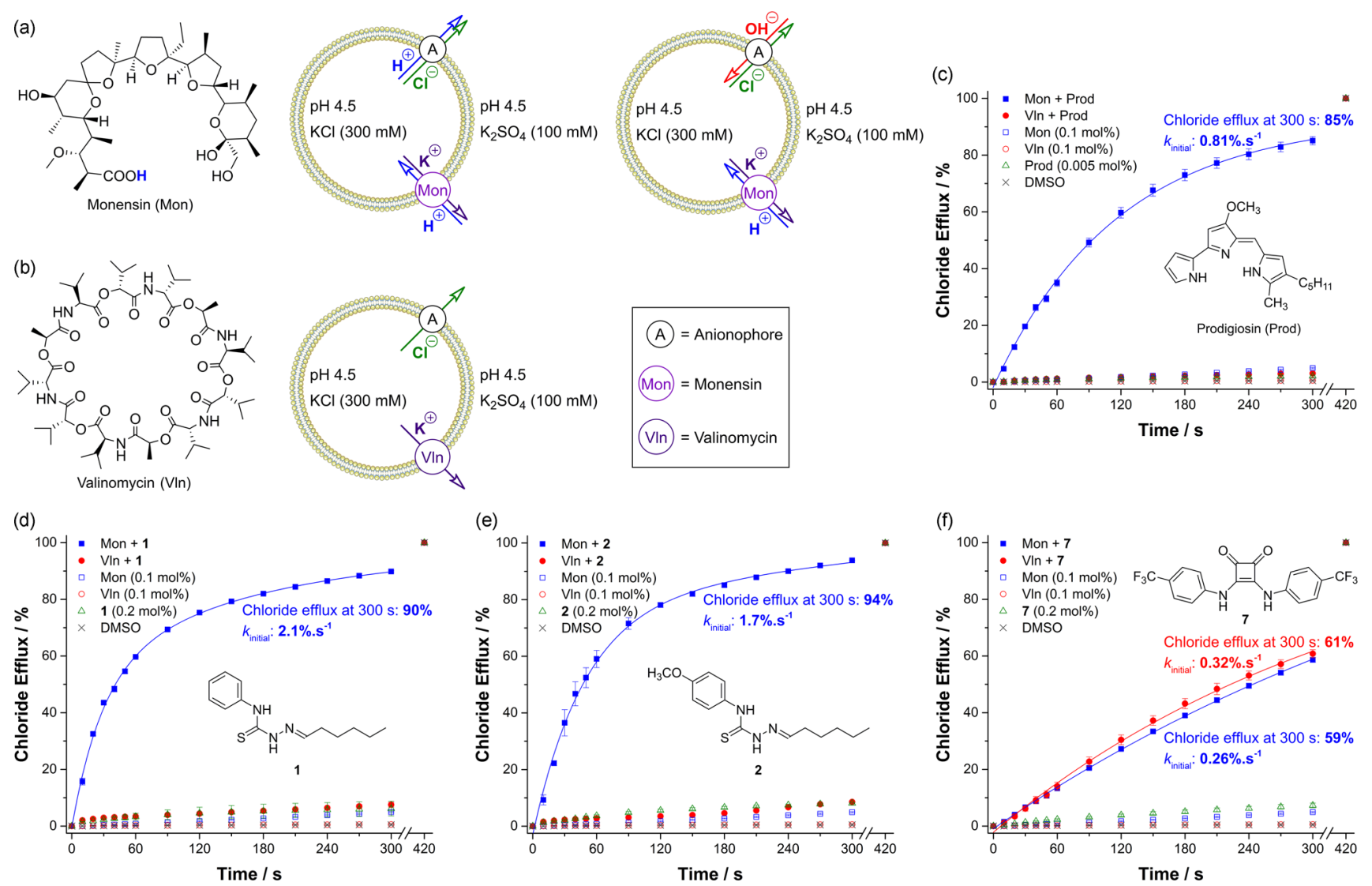

Figure 7. Overview of cationophore-coupled $\mathrm{KCl}$ efflux assays, measured by chloride-ISE from POPC LUVs (mean diameter $200 \mathrm{~nm}$ ) loaded with $\mathrm{KCl}(300 \mathrm{mM})$ and suspended in $\mathrm{K}_{2} \mathrm{SO}_{4}(100 \mathrm{mM})$, adjusted to $\mathrm{pH} 4.5$ with $\mathrm{KOH}$ in citrate $(5.0 \mathrm{mM})$ : (a) structure of monensin, and schematic diagrams showing overall $\mathrm{KCl}$ net flux induced by the combination of electroneutral transport processes, including monensin's $\mathrm{K}^{+} / \mathrm{H}^{+}$exchange and the anionophore's $\mathrm{H}^{+} / \mathrm{Cl}^{-}$cotransport or $\mathrm{Cl}^{-} / \mathrm{OH}^{-}$exchange; (b) structure of valinomycin, and schematic diagram showing overall $\mathrm{KCl}$ net flux from the combination of electrogenic $\mathrm{Cl}^{-}$efflux facilitated by anionophore, coupled to the electrogenic $\mathrm{K}^{+}$transport mediated by valinomycin; $(\mathrm{c}-\mathrm{f}$ ) plots of $\mathrm{Cl}^{-}$efflux facilitated by anionophores (prodigiosin, thiosemicarbazones $\mathbf{1}$ and 2, and squaramide 7) in the absence or presence of cationophores (monensin or valinomycin) monitored over a period of $5 \mathrm{~min}$, and detergent was added to lyse the vesicles at $300 \mathrm{~s}$, to release remaining encapsulated $\mathrm{Cl}^{-}$for the $100 \%$ chloride concentration at $420 \mathrm{~s}$. All ionophores were added as DMSO solutions (10 $\left.\mu \mathrm{L}\right)$ to the POPC LUVs suspension $(5.0 \mathrm{~mL})$, the lipid concentration used was $1.0 \mathrm{mM}$, and loading concentrations of ionophores are shown as carrier:lipid molar percent. Solid lines are fitted curves using exponential functions to calculate the initial rate $\left(k_{\text {initial }}\right)$ of $\mathrm{Cl}^{-}$efflux, shown as $\% . \mathrm{s}^{-1}$; error bars correspond to the SD from two repeats. Same DMSO, monensin, and valinomycin controls are used in all four plots. 
basic in both aqueous and lipid bilayer membrane environments; therefore, compound $\mathbf{1}$ is a better $\mathrm{pH}$-switchable anion transporter than 2, as shown by the higher $\mathrm{EC}_{50}(\mathrm{pH} 7.2) /$ $\mathrm{EC}_{50}(\mathrm{pH} 4.0)$ ratio. Compound $3\left(-\mathrm{CF}_{3}\right)$ is more acidic than $\mathbf{1}$, and this is demonstrated by the fully switched-OFF transport activity at $\mathrm{pH} 7.2$ (Figure 4). The transport activities for 1-3 are all fully switched OFF at $\mathrm{pH} 10.0$ (see Supporting Information Figure S38), indicating that the thiosemicarbazones must be protonated to mediate transport of anions.

Nonelectrogenic Transport Mechanistic Studies. By using the combination of two complementary cationophorecoupled $\mathrm{KCl}$ efflux assays (Figure $7 \mathrm{a}$ and $7 \mathrm{~b}$ ), we can effectively identify two different types of anion transport mechanisms that cannot be revealed using $\mathrm{Cl}^{-} / \mathrm{NO}_{3}^{-}$exchange experiments: electrogenic chloride transport and electroneutral $\mathrm{H}^{+} / \mathrm{Cl}^{-}$ cotransport. In an electrogenic process, there is a net flow of charge across a membrane (Figure $7 \mathrm{~b}$ ). In an electroneutral process (Figure $7 \mathrm{a}$ ), the charge is balanced either by back transport of a species with the same charge (i.e., $\mathrm{Cl}^{-} / \mathrm{OH}^{-}$ exchange) or cotransport of a species with opposite charge $\left(\mathrm{H}^{+} / \mathrm{Cl}^{-}\right)$. Monensin and valinomycin are naturally occurring cationophores, but their underlying transport mechanisms are fundamentally different. Monensin has a single carboxylic acid group that deprotonates upon metal complexation to form a pseudomacrocyclic complex. It therefore functions as a $\mathrm{M}^{+} / \mathrm{H}^{+}$ antiporter (exchanger) in lipid bilayer membrane transport, with negligible activity in facilitating $\mathrm{M}^{+}$transport. ${ }^{30}$ This is an electroneutral cation exchange process and will result in perturbation of luminal $\mathrm{pH}$. In contrast, valinomycin is a $\mathrm{K}^{+}$selective carrier; it facilitates electrogenic $\mathrm{K}^{+}$transport without directly affecting the transmembrane $\mathrm{pH}$ gradient. ${ }^{31}$

Liposomes were loaded with $\mathrm{KCl}$ and suspended in $\mathrm{K}_{2} \mathrm{SO}_{4}$ external solution, with both solutions buffered to $\mathrm{pH} 4.5$ with citrate. Either monensin $(0.1 \mathrm{~mol} \%)$ or valinomycin $(0.1 \mathrm{~mol}$ $\%)$ was added alone or in combination with an anionophore $(0.2 \mathrm{~mol} \%)$ or prodigiosin $(0.005 \mathrm{~mol} \%)$, and the rate of $\mathrm{Cl}^{-}$ efflux was monitored by a chloride ion-selective electrode. In these cationophore-coupled assays, chloride efflux is driven by the large $\mathrm{Cl}^{-}$concentration gradient. In the presence of an $\mathrm{H}^{+}$/ $\mathrm{Cl}^{-}$cotransporter alone, no measurable $\mathrm{Cl}^{-}$efflux could occur due to the buildup of transmembrane $\mathrm{pH}$ gradient. For this reason, prodigiosin must couple with monensin to combine $\mathrm{H}^{+} / \mathrm{Cl}^{-}$symport and $\mathrm{K}^{+} / \mathrm{H}^{+}$antiport, resulting in formal $\mathrm{KCl}$ efflux (Figure 7c). No measurable $\mathrm{Cl}^{-}$efflux was observed when prodigiosin was added with valinomycin (Figure 7c), consistent with the nonelectrogenic nature of prodigiosin. ${ }^{5}$

Figure $7 \mathrm{f}$ shows that compound 7 can couple with both monensin and valinomycin to facilitate $\mathrm{KCl}$ efflux. We have previously shown that this is because simple neutral hydrogen bonding anionophores such as 7 are nonspecific and can function both as an electrogenic chloride transporter that can couple with valinomycin and also as a $\mathrm{H}^{+}$transporter or functionally equivalent $\mathrm{OH}^{-}$transporter; hence, these processes together with $\mathrm{Cl}^{-}$transport can couple with the electroneutral $\mathrm{K}^{+} / \mathrm{H}^{+}$transport by monensin. ${ }^{19}$

When thiosemicarbazones were examined in these assays, it was found that $\mathrm{Cl}^{-}$efflux is only observed in the presence of monensin but not valinomycin. This experiment demonstrates that $\mathrm{K}^{+} / \mathrm{H}^{+}$antiport facilitated by monensin couples to $\mathrm{H}^{+} / \mathrm{Cl}^{-}$ cotransport facilitated by the thiosemicarbazone, resulting in overall $\mathrm{KCl}$ efflux from the liposomes. Importantly, as no chloride efflux is observed in the presence of valinomycin, this experiment demonstrates that the $\mathrm{H}^{+}$and $\mathrm{Cl}^{-}$transport facilitated by the thiosemicarbazone is an inseparable process (Figure $7 \mathrm{~d}$ and $7 \mathrm{e}$ ). Therefore, thiosemicarbazones are prodigiosin-like, in which chloride cannot be transported without a proton also being transported, and the protonated thiosemicarbazones cannot diffuse through the lipid bilayer without a counteranion. Also of note, the initial rates $\left(k_{\text {initial }}\right)$ of $\mathrm{Cl}^{-}$efflux from these cationophore-coupled assays gave the same trend (e.g., 1 faster than 2) for the $\mathrm{Cl}^{-} / \mathrm{NO}_{3}{ }^{-}$exchange assay discussed above, indicating that the electrogenic $\mathrm{Cl}^{-}$or electroneutral $\mathrm{H}^{+} / \mathrm{Cl}^{-}$(or $\mathrm{Cl}^{-} / \mathrm{OH}^{-}$) transport facilitated by anionophores is the rate-limiting flux process with $0.1 \mathrm{~mol} \%$ of cationophore loading.

These results taken together are evidence that thiosemicarbazones must be protonated at the imino nitrogen to switch ON transmembrane transport of chloride (Figure 8). This

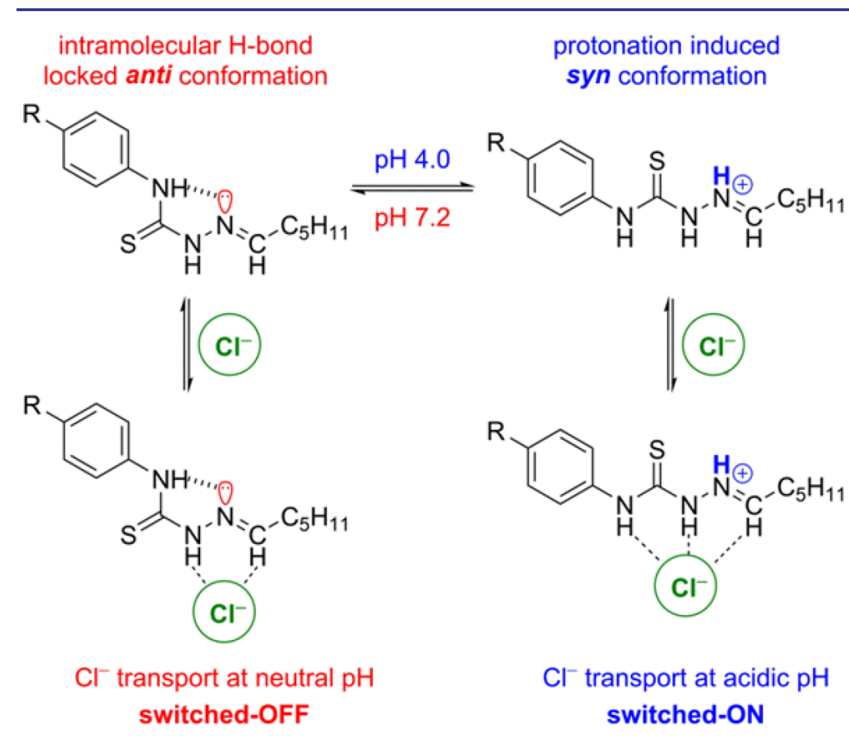

Figure 8. Schematic overview for the acid-sensing (proton-gated) ON/OFF chloride transport mechanism of thiosemicarbazones.

results in cotransport of $\mathrm{H}^{+} / \mathrm{Cl}^{-}$, mimicking the nonelectrogenic $\mathrm{H}^{+} / \mathrm{Cl}^{-}$symport mechanism of prodigiosin (Figure 1), which is fundamentally different from previously reported $\mathrm{pH}$ dependent nonspecific transporters, which are able to mediate both electroneutral and electrogenic transport processes. This is important, as electrogenic transporters are known to depolarize mitochondria membrane potential ${ }^{13}$ which can complicate biological studies of cellular processes. ${ }^{14}$ Furthermore, the $\mathrm{EC}_{50}$ of thiosemicarbazones $\mathbf{1}$ and $\mathbf{2}$ (Table 1 ) are significantly lower than the analogous phenylthioureas $\mathbf{4}$ and $\mathbf{5}$ and are also comparable to some of the most potent synthetic anionophores reported to date, ${ }^{32}$ hence suggesting that an overall neutral complex (e.g., $\mathbf{1} \cdot \mathrm{H}^{+} \supset \mathrm{Cl}^{-}$) is favorable in the transport process.

\section{CONCLUSIONS}

We have shown that phenylthiosemicarbazones are the first examples of nonelectrogenic anion transporters that show $\mathrm{pH}$ switching behavior between neutral and acidic $\mathrm{pH}$ conditions. The $\mathrm{pH}$-switchable transport properties are very significant, in particular compound 1 which has an $\mathrm{EC}_{50}$ value 640 -fold times lower at $\mathrm{pH} 4.0$ than at $\mathrm{pH} 7.2$ (i.e., it is a significantly better transporter under acidic conditions). The nonelectrogenic $\mathrm{H}^{+}$/ $\mathrm{Cl}^{-}$cotransport mechanism was shown to mimic that of prodigiosin by using cationophore-coupled $\mathrm{KCl}$ efflux assays. In the search for more effective anionophores tailored for different 
biological studies, this work in conjunction with our most recent work (on the study of electrogenic anionophores) ${ }^{19}$ has shown the importance of elucidating the fundamental transport mechanism, as most reported synthetic anionophores are nonspecific, capable of mediating both electrogenic and nonelectrogenic processes. The explicit $\mathrm{pH}$-switchable transport at $\mathrm{pH} 4.0$ demonstrated by this class of transporters could potentially be employed for targeted anion efflux from acidic lysosomal vesicles in cells, gaining new insights into cellular processes induced by anionophores.

\section{ASSOCIATED CONTENT}

\section{S Supporting Information}

The Supporting Information is available free of charge on the ACS Publications website at DOI: 10.1021/jacs.6b04656.

Details of synthesis, characterization, NMR and MS spectra, and single-crystal X-ray analysis of 1-3 and 10; methodology of anion binding studies, and ${ }^{1} \mathrm{H}$ NMR titration fitted binding isotherms; 2-D NOESY ${ }^{1} \mathrm{H}-{ }^{1} \mathrm{H}$ NMR spectra of conformational studies; ${ }^{1} \mathrm{H}$ NMR spectra of $\mathrm{HBF}_{4}$ titration studies; UV-vis spectra of stability studies; details on computational and $\mathrm{p} K_{\mathrm{a}}$ studies; details on anion transport studies in various liposome-based assays, along with fitted plots of Hill analysis and initial rate studies. (PDF)

Crystallographic data (CIF)

The data underlying this paper have been made available online at http://dx.doi.org/10.5258/SOTON/396680 to comply with the EPSRC open data policy.

\section{AUTHOR INFORMATION}

\section{Corresponding Authors}

*philip.gale@soton.ac.uk

*j.a.kitchen@soton.ac.uk

\section{Present Address}

${ }^{\ddagger}$ Silver Center for Arts and Science, Department of Chemistry, New York University, 100 Washington Square East, New York, NY 10003.

\section{Notes}

The authors declare no competing financial interest.

\section{ACKNOWLEDGMENTS}

P.A.G. thanks the EPSRC for funding (EP/J009687/1) and the Royal Society and the Wolfson Foundation for a Research Merit Award. P.A.G. also thanks the University of Southampton together with the A*STAR ARAP Programme (Singapore) for a studentship (SNB). P.A.G. and X.W. thank the University of Southampton together with the China Scholarship Council for a studentship. J.H. acknowledges support from $A^{*}$ STAR and provision of computing time from the NCI. We thank the EPSRC for use of the X-ray Crystallographic facilities at the University of Southampton. ${ }^{33}$ The authors would also like to thank Dr. Neil J. Wells from the University of Southampton for his advice and assistance with NMR spectroscopy.

\section{REFERENCES}

(1) (a) Gadsby, D. C. Nat. Rev. Mol. Cell Biol. 2009, 10, 344-352. (b) Ashcroft, F. M. Ion Channels and Disease; Academic Press: San Diego, 2000.

(2) For reviews, see (a) Busschaert, N.; Caltagirone, C.; Van Rossom, W.; Gale, P. A. Chem. Rev. 2015, 115, 8038-8155. (b) Gale, P. A.; Pérez-Tomás, R.; Quesada, R. Acc. Chem. Res. 2013, 46, 2801-2813. (c) Busschaert, N.; Gale, P. A. Angew. Chem., Int. Ed. 2013, 52, 13741382. (d) Matile, S.; Vargas Jentzsch, A.; Montenegro, J.; Fin, A. Chem. Soc. Rev. 2011, 40, 2453-2474. (e) Davis, J. T.; Okunola, O.; Quesada, R. Chem. Soc. Rev. 2010, 39, 3843-3862. For a selection of related studies, see (f) Li, H.; Valkenier, H.; Judd, L. W.; Brotherhood, P. R.; Hussain, S.; Cooper, J. A.; Jurček, O.; Sparkes, H. A.; Sheppard, D. N.; Davis, A. P. Nat. Chem. 2016, 8, 24-32. (g) Ko, S.-K.; Kim, S. K.; Share, A.; Lynch, V. M.; Park, J.; Namkung, W.; Van Rossom, W.; Busschaert, N.; Gale, P. A.; Sessler, J. L.; Shin, I. Nat. Chem. 2014, 6, 885-892. (h) Valkenier, H.; Judd, L. W.; Li, H.; Hussain, S.; Sheppard, D. N.; Davis, A. P. J. Am. Chem. Soc. 2014, 136, 12507-12512. (i) Moore, S. J.; Wenzel, M.; Light, M. E.; Morley, R.; Bradberry, S. J.; Gómez-Iglesias, P.; Soto-Cerrato, V.; Pérez-Tomás, R.; Gale, P. A. Chem. Sci. 2012, 3, 2501-2509. (j) Vargas Jentzsch, A.; Emery, D.; Mareda, J.; Nayak, S. K.; Metrangolo, P.; Resnati, G.; Sakai, N.; Matile, S. Nat. Commun. 2012, 3, 905. (k) Shen, B.; Li, X.; Wang, F.; Yao, X.; Yang, D. PLoS One 2012, 7, e34694. (1) Busschaert, N.; Wenzel, M.; Light, M. E.; Iglesias-Hernández, P.; Pérez-Tomás, R.; Gale, P. A. J. Am. Chem. Soc. 2011, 133, 14136-14148. (m) Dawson, R. E.; Hennig, A.; Weimann, D. P.; Emery, D.; Ravikumar, V.; Montenegro, J.; Takeuchi, T.; Gabutti, S.; Mayor, M.; Mareda, J.; Schalley, C. A.; Matile, S. Nat. Chem. 2010, 2, 533-538. (n) Gale, P. A.; Tong, C. C.; Haynes, C. J. E.; Adeosun, O.; Gross, D. E.; Karnas, E.; Sedenberg, E. M.; Quesada, R.; Sessler, J. L. J. Am. Chem. Soc. 2010, 132, 3240-3241. (o) Davis, J. T.; Gale, P. A.; Okunola, O. A.; Prados, P.; IglesiasSánchez, J. C.; Torroba, T.; Quesada, R. Nat. Chem. 2009, 1, 138-144.

(3) (a) Williamson, N. R.; Fineran, P. C.; Leeper, F. J.; Salmond, G. P. C. Nat. Rev. Microbiol. 2006, 4, 887-899. (b) Ohkuma, S.; Sato, T.; Okamoto, M.; Matsuya, H.; Arai, K.; Kataoka, T.; Nagai, K.; Wasserman, H. H. Biochem. J. 1998, 334, 731-741.

(4) (a) Pérez-Tomás, R.; Montaner, B.; Llagostera, E.; Soto-Cerrato, V. Biochem. Pharmacol. 2003, 66, 1447-1452. (b) Montaner, B.; Pérez-Tomás, R. Life Sci. 2001, 68, 2025-2036.

(5) Sato, T.; Konno, H.; Tanaka, Y.; Kataoka, T.; Nagai, K.; Wasserman, H. H.; Ohkuma, S. J. Biol. Chem. 1998, 273, 2145521462.

(6) Seganish, J. L.; Davis, J. T. Chem. Commun. 2005, 5781-5783.

(7) (a) Knight, N. J.; Hernando, E.; Haynes, C. J. E.; Busschaert, N.; Clarke, H. J.; Takimoto, K.; García-Valverde, M.; Frey, J. G.; Quesada, R.; Gale, P. A. Chem. Sci. 2016, 7, 1600-1608. (b) Soto-Cerrato, V.; Manuel-Manresa, P.; Hernando, E.; Calabuig-Fariñas, S.; MartínezRomero, A.; Fernández-Dueñas, V.; Sahlholm, K.; Knöpfel, T.; GarcíaValverde, M.; Rodilla, A. M.; Jantus-Lewintre, E.; Farràs, R.; Ciruela, F.; Pérez-Tomás, R.; Quesada, R. J. Am. Chem. Soc. 2015, 137, 1589215898. (c) Hernando, E.; Soto-Cerrato, V.; Cortés-Arroyo, S.; PérezTomás, R.; Quesada, R. Org. Biomol. Chem. 2014, 12, 1771. (d) Hernández, P. I.; Moreno, D.; Javier, A. A.; Torroba, T.; PérezTomás, R.; Quesada, R. Chem. Commun. 2012, 48, 1556-1558.

(8) Van Rossom, W.; Asby, D. J.; Tavassoli, A.; Gale, P. A. Org. Biomol. Chem. 2016, 14, 2645-2650.

(9) (a) Díaz de Greñu, B.; Hernández, P. I.; Espona, M.; Quiñonero, D.; Light, M. E.; Torroba, T.; Pérez-Tomás, R.; Quesada, R. Chem. Eur. J. 2011, 17, 14074-14083. (b) Sessler, J. L.; Eller, L. R.; Cho, W.S.; Nicolaou, S.; Aguilar, A.; Lee, J. T.; Lynch, V. M.; Magda, D. J. Angew. Chem., Int. Ed. 2005, 44, 5989-5992. (c) Gale, P. A.; Light, M. E.; McNally, B.; Navakhun, K.; Sliwinski, K. E.; Smith, B. D. Chem. Commun. 2005, 3773-3775.

(10) (a) Wemmie, J. A.; Taugher, R. J.; Kreple, C. J. Nat. Rev. Neurosci. 2013, 14, 461-471. (b) Li, T.; Yang, Y.; Canessa, C. M. Nat. Commun. 2011, 2, 399. (c) Jasti, J.; Furukawa, H.; Gonzales, E. B.; Gouaux, E. Nature 2007, 449, 316-323.

(11) (a) Santacroce, P. V.; Davis, J. T.; Light, M. E.; Gale, P. A.; Iglesias-Sánchez, J. C.; Prados, P.; Quesada, R. J. Am. Chem. Soc. 2007, 129, 1886-1887. (b) Rastogi, S.; Marchal, E.; Uddin, I.; Groves, B.; Colpitts, J.; McFarland, S. A.; Davis, J. T.; Thompson, A. Org. Biomol. Chem. 2013, 11, 3834-3845.

(12) (a) Busschaert, N.; Elmes, R. B. P.; Czech, D. D.; Wu, X.; Kirby, I. L.; Peck, E. M.; Hendzel, K. D.; Shaw, S. K.; Chan, B.; Smith, B. D.; Jolliffe, K. A.; Gale, P. A. Chem. Sci. 2014, 5, 3617-3626. (b) Elmes, R. 
B. P.; Busschaert, N.; Czech, D. D.; Gale, P. A.; Jolliffe, K. A. Chem. Commun. 2015, 51, 10107-10110.

(13) Läuger, P. Angew. Chem., Int. Ed. Engl. 1985, 24, 905-923.

(14) (a) Kroemer, G.; Jaattela, M. Nat. Rev. Cancer 2005, 5, 886897. (b) Ferri, K. F.; Kroemer, G. Nat. Cell Biol. 2001, 3, E255-E263.

(15) (a) Raposo, M. M. M.; García-Acosta, B.; Ábalos, T.; Calero, P.; Martínez-Máñez, R.; Ros-Lis, J. V.; Soto, J. J. Org. Chem. 2010, 75, 2922-2933. (b) Amendola, V.; Boiocchi, M.; Fabbrizzi, L.; Mosca, L. Chem. - Eur. J. 2008, 14, 9683-9696. (c) Vázquez, M.; Fabbrizzi, L.; Taglietti, A.; Pedrido, R. M.; González-Noya, A. M.; Bermejo, M. R. Angew. Chem., Int. Ed. 2004, 43, 1962-1965.

(16) (a) Hammett, L. P. J. Am. Chem. Soc. 1937, 59, 96-103. (b) Hansch, C.; Leo, A.; Taft, R. W. Chem. Rev. 1991, 91, 165-195. (17) (a) Tresca, B. W.; Hansen, R. J.; Chau, C. V.; Hay, B. P.; Zakharov, L. N.; Haley, M. M.; Johnson, D. W. J. Am. Chem. Soc. 2015, 137, 14959-14967. (b) Adriaenssens, L.; Gil-Ramírez, G.; Frontera, A.; Quiñonero, D.; Escudero-Adán, E. C.; Ballester, P. J. Am. Chem. Soc. 2014, 136, 3208-3218. (c) Busschaert, N.; Bradberry, S. J.; Wenzel, M.; Haynes, C. J. E.; Hiscock, J. R.; Kirby, I. L.; Karagiannidis, L. E.; Moore, S. J.; Wells, N. J.; Herniman, J.; Langley, G. J.; Horton, P. N.; Light, M. E.; Marques, I.; Costa, P. J.; Félix, V.; Frey, J. G.; Gale, P. A. Chem. Sci. 2013, 4, 3036-3045.

(18) Busschaert, N.; Kirby, I. L.; Young, S.; Coles, S. J.; Horton, P. N.; Light, M. E.; Gale, P. A. Angew. Chem., Int. Ed. 2012, 51, 44264430.

(19) Wu, X.; Judd, L. W.; Howe, E. N. W.; Withecombe, A. M.; SotoCerrato, V.; Li, H.; Busschaert, N.; Valkenier, H.; Pérez-Tomás, R.; Sheppard, D. N.; Jiang, Y.-B.; Davis, A. P.; Gale, P. A. Chem 2016, DOI: $10.1016 /$ j.chempr.2016.04.002.

(20) (a) Noto, R.; Meo, P. L.; Gruttadauria, M.; Werber, G. J. Heterocycl. Chem. 1996, 33, 863-872. (b) Noto, R; Buccheri, F.; Cusmano, G.; Gruttadauria, M.; Werber, G. J. Heterocycl. Chem. 1991, $28,1421-1427$

(21) (a) Howe, E. N. W.; Bhadbhade, M.; Thordarson, P. J. Am. Chem. Soc. 2014, 136, 7505-7516. (b) Gutmann, V. The DonorAcceptor Approach to Molecular Interactions; Plenum Press: New York, 1978.

(22) (a) Thordarson, P. Chem. Soc. Rev. 2011, 40, 1305-1323. (b) www.supramolecular.org (accessed February 15, 2016).

(23) (a) Hill, A. V. Biochem. J. 1913, 7, 471-480. (b) Bhosale, S.; Matile, S. Chirality 2006, 18, 849-856. (c) Matile, S.; Sakai, N. In Analytical Methods in Supramolecular Chemistry; 2nd ed.; Schalley, C. A., Ed.; Wiley-VCH Verlag GmbH \& Co. KGaA: Weinheim, Germany, 2012; pp 711-742.

(24) (a) Tetko, I. V.; Gasteiger, J.; Todeschini, R.; Mauri, A.; Livingstone, D.; Ertl, P.; Palyulin, V. A.; Radchenko, E. V.; Zefirov, N. S.; Makarenko, A. S.; Tanchuk, V. Y.; Prokopenko, V. V. J. Comput.Aided Mol. Des. 2005, 19, 453-463. (b) Virtual Computational Chemistry Laboratory. www.vcclab.org (accessed February 11, 2016).

(25) Campbell, M. J. M. Coord. Chem. Rev. 1975, 15, 279-319.

(26) Dempsey, C. E. Prog. Nucl. Magn. Reson. Spectrosc. 2001, 39, 135-170. Variable temperature ${ }^{1} \mathrm{H}$ NMR studies were attempted at 298, 273, 213, and $183 \mathrm{~K}$ for thiosemicarbazones 1 and 2 (in the presence of 1.0 equiv of $\mathrm{HBF}_{4}$ ); however, the proton chemical exchange was too fast to be observed. This is likely due to the effect of acid-catalyzed rapid exchange for the more acidic/labile protons.

(27) (a) Marenich, A. V.; Cramer, C. J.; Truhlar, D. G. J. Phys. Chem. B 2009, 113, 6378-6396. (b) Zhao, Y.; Truhlar, D. G. Theor. Chem. Acc. 2008, 120, 215-241.

(28) Ho, J.; Coote, M. Theor. Chem. Acc. 2010, 125, 3-21.

(29) (a) Ozaki, S.; Shirai, O.; Kihara, S.; Kano, K. Electrochem. Commun. 2007, 9, 2266-2270. (b) Ozaki, S.; Kano, K.; Shirai, O. Phys. Chem. Chem. Phys. 2008, 10, 4449-4455.

(30) Mollenhauer, H. H.; James Morré, D.; Rowe, L. D. Biochim. Biophys. Acta, Rev. Biomembr. 1990, 1031, 225-246.

(31) Pressman, B. C. Annu. Rev. Biochem. 1976, 45, 501-530.

(32) Karagiannidis, L. E.; Haynes, C. J. E.; Holder, K. J.; Kirby, I. L.; Moore, S. J.; Wells, N. J.; Gale, P. A. Chem. Commun. 2014, 50, 12050-12053.
(33) Coles, S. J.; Gale, P. A. Chem. Sci. 2012, 3, 683-689. 